\title{
SISTEM PAKAR UNTUK MENDIAGNOSA GANGGUAN PADA SISTEM HEPATOBILIARIS BERBASIS ANDROID MOBILE
}

\author{
Redo Abeputra Sihombing \\ Informatika, Universitas Indraprasta PGRI \\ redoabe@gmail.com
}

\begin{abstract}
Abstrak
Gangguan pada sistem Hepatobiliaris merupakan masalah kesehatan yang sering dijumpai, bahkan terus berkembang, sehingga untuk mengetahui hasil diagnosis akan sulit. Cara yang lebih baik adalah berkonsultasi bersama pakar atau dokter ahli. Namun ada pula kelemahannya seperti tenaga ahli yang terbatas atau jam kerja yang terbilang pendek. Sistem pakar adalah salah satu ilmu kecerdasan buatan atau biasa di sebut (artificial intelligence) yaitu ilmu yang mempelajari serta mengadopsi cara seorang pakar berpikir dalam menyelesaikan suatu permasalahan serta membuat suatu keputusan maupun simpulan. Permasalahan yang dibahas adalah bagaimana merancang sistem yang dapat digunakan untuk menyelesaikan permasalahan di atas. Maksud dan tujuan penulis dalam membuat sisem pakar ini adalah untuk membantu calon dokter dalam mendiagnosa gangguan pada sistem Hepatobiliaris layaknya seorang pakar. Sistem pakar menggunakan metode Best First Search dan menggunakan teknik Forward Chaining. Di dalam sistem ini dituangkan pengetahuan seorang pakar yang di dapat selama melakukan research di Rumah Sakit Permata Ibu. Sebuah sistem pakar dikembangkan berbasis Android pada sisi client, $P H P$ dan MySQL. Sistem pakar menampilkan gejala-gejala yang dapat dipilih oleh user, dimana gejala itu akan membawa user ke pilihan gejala selanjutnya sehingga mendapatkan simpulan.
\end{abstract}

Kata Kunci : Sistem Pakar, Hepatobiliaris, Best First Search, Forward Chaning.

\begin{abstract}
Disturbances in the Hepatobiliaris system are health problems that are often encountered, even growing, so to know the diagnosis will be difficult. A better way is to consult an expert or an expert doctor. But there are also weaknesses such as working hours or limited experts. Expert system is one branch of artificial intelligence that learns how to adopt the way an expert thinks in solving a problem and make decisions and conclusions. The problem discussed is how to design a system that can be used to solve the above problems. The purpose and objective of the author in making this expert sisem is to assist the prospective physician in diagnosing disorders of the Hepatobiliaris system like an expert. Expert system using Best First Search method and using Forward Chaining technique. In this system poured knowledge of an expert in the can during research at Permata Ibu Hospital. An expert system developed based on Android on the client side, PHP and MySQL. This expert system displays a selection of symptoms that can be selected by the user, where each choice of symptoms that will lead the user to the next symptom option to get the conclusion.
\end{abstract}

Key Words : Expert System, Hepatobiliary, Best First Search, Forward Chaning.

\section{PENDAHULUAN}

Gangguan pada sistem Hepatobiliaris (Hati, Empedu dan Pankreas) merupakan masalah kesehatan yang sering dijumpai dan terus berkembang, sehingga untuk mengetahui hasil diagnosis akan sulit. Akibatnya tak jarang keluhan - keluhan di daerah tersebut ditangani dengan cara yang salah karena kurangnya knowledge maupun pengalaman. Pemeriksaan laboratorium bisa jadi alternatif yang dapat dilakukan untuk mendapatkan hasil diagnosis yang lebih baik. Namun, membutuh waktu yang lama dan biaya yang relatif mahal untuk mengetahui hasil diagnosisnya, selain itu belum semua rumah sakit di Indonesia memiliki fasilitas laboratorium yang memadai. Cara yang lebih baik adalah berkonsultasi bersama 
pakar atau dokter ahli. Namun kelemahannya seperti tenaga ahli yang terbatas atau jam kerja yang terbilang pendek. Karena hal tersebutlah maka dibutuhkan suatu alat bantu yang dapat mendiagnosis gangguan pada sistem Hepatobiliaris (Hati, Empedu dan Pankreas).

Sistem pakar adalah salah satu ilmu kecerdasan buatan atau biasa di sebut (artificial intelligence) yaitu ilmu yang mempelajari serta mengadopsi cara seorang pakar berpikir dalam menyelesaikan suatu permasalahan serta membuat suatu keputusan maupun simpulan [1].

Permasalahan yang akan dibahas adalah bagaimana merancang sebuah sistem yang dapat digunakan untuk membantu diagnosis gangguan atau penyakit yang di alami pasien pada sistem Hepatobiliaris (Hati, Empedu dan Pankreas) berdasarkan gejala yang dirasakan pasien, sehingga user dapat memberikan saran atas rasa sakit yang dihadapi.

\section{METODE PENELITIAN}

Pada penelitian ini, metode yang digunakan yaitu metode waterfall. Metode waterfall adalah model klasik yang bersifat sistematis, berurutan dalam membangun software [2]. Metode waterfall ini dimulai analisis, desain, pengodean, pengujian, dan maintenance.

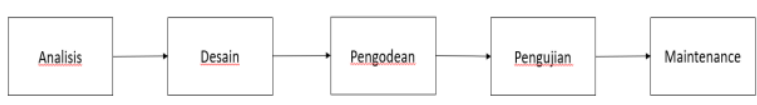

Gambar 1. Metode Waterfall

Pada tahap analisis membutuhkan data sebagai rancangan awal sebelum membuat desain maupun aplikasi. Teknik pengumpulan data pada tahap analisis ini yaitu menggunakan teknik wawancara dimana disini diajukan beberapa pertanyaan - pertanyaan kepada pakar atau disini dokter ahli yang telah mengerti bagaimana sistem hepatobiiaris bekerja dan gejala - gejala apa saja yang biasanya terjadi. Ditambah dengan studi literatur mengenai sistem hepatobiliaris yaitu data diambil dari buku - buku mengenai penanganan maupun buku besar kedokteran mengenai penyakit maupun gejala - gejala yang terjadi pada sistem hepatobiliaris. Dilanjutkan pada tahap design sistem pakar dirancang menggunaan perangkat mobile (android). Sehingga pengguna dapat dengan mudah mengakses atau menggunakan aplikasi.

Sistem pakar yang di rancang ini terdiri dari dua bagian pada sisi server yang dibuatkan dengan Bahasa pemrograman PHP sebagai mesin inferensi (inference engine). Knowledge / basis pengetahuan disimpan di dalam MySQL database. Lalu Mobile Phone (Android) pada bagian client. Client dan Sever terhubung melalui internet kemudian keduanya berkomunikasi menggunakan metode request dan response yaitu dimana client (android) meminta data ke server dan server akan memberikan data kembali ke client (android). Salah satu komponen penting dari sistem pakar adalah basis pengetahuan (knowledge base). Seorang pakar dapat menyusun basis pengetahuan mereka ataupun dari literatur yang didapat untuk menemukan fakta-fakta atau sumber yang terpecaya dalam penelitian ini yang ada kaitannya tentang sistem hepatobiliaris. Sehingga didapatkan 40 rule dan 5 level kedalaman pertanyaan yang di ajukan sehingga menjadi membentuk pohon keputusan. Berikut ini contoh rule dalam kasus penelitian pada sistem hepatobiliaris [3] :JIKA pasien mengalami ikterus

DAN mengalami demam

DAN mengalami mual

DAN ada hepatomegaly

DAN nyeri pada tulang 
MAKA menderita penyakit Hepatitis Virus A

Seluruh rule harus disimpan di dalam database dengan menerapkan teknik penalaran dan teknik penelusuran yang kita pilih.

Ada dua teknik yang dapat dilakukan dalam melakukan penalaran (inference) [4]:

1) Pelacakan Kedepan (Forward Chaning)

Dari sekumpulan data yang berupa fakta-fakta yang dihadapi dengan mencari kemungkinan yang cocok dengan hipotesa sehingga menjadi sebuah simpulan.

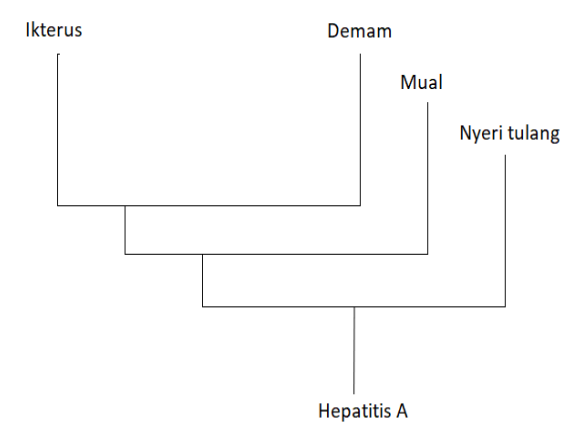

Gambar 2. Forward Chaning

2) Pelacakan Kebelakang (Backward Chaning)

Di mulai dari simpulan dengan mencari sekumpulan gejala - gejala yang mendukung menuju fakta - fakta dari sekumpulan hipotesa tersebut.

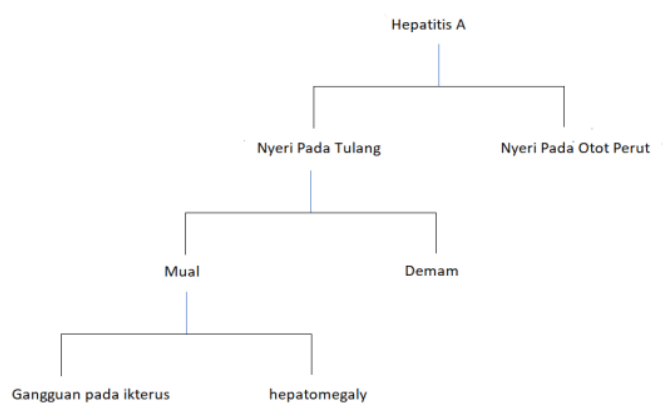

Gambar 3. Backward Chaning
Kedua teknik penalaran dipengaruhi oleh tiga macam teknik penelusuran (searching):

1) Teknik Depth First Search

Teknik penelusuran ini digunakan pada data yang sudah terdefinisi, misal dari sisi kiri ke sisi kanan, keuntungan dengan mengunakan pencarian teknik ini adalah masalah dapat di gali secara mendalam dapat di telusuri sampai di temukannya suatu solusi yang optimal. Tetapi kekurangan teknik ini adalah penelusuran dalam mencari solusi yang optimal membutuhkan waktu yang sangat lama untuk kasus ruang lingkup masalah yang besar.

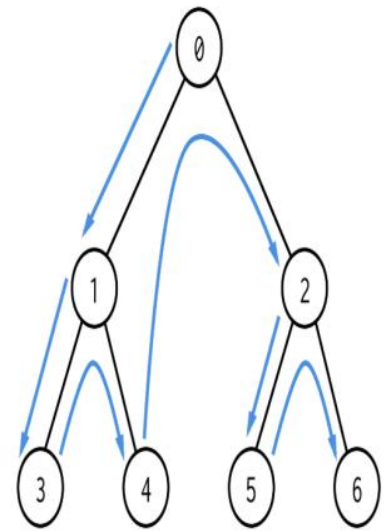

\section{Gambar 4. Depth First Search}

2) Teknik Breadth First Search

Teknik penelusuran ini menelusuri node pada satu level terlebih dahulu atau satu tingkatan sebelum nantinya pindah ke level atau tingkatan di bawahnya. Keuntungan pencarian dengan teknik ini sama dengan DepthFirst Search, hanya saja penelusuran seperti ini mempunyai nilai tambah, dimana semua node akan di cek secara menyeluruh pada setiap tingkatan node. Kekurangan teknik ini tetap terletak pada waktu yang dibutuhkan saat proses berlangsung sangat lama apabila solusi berada dalam posisi node terakhir sangat tidak efisien. 


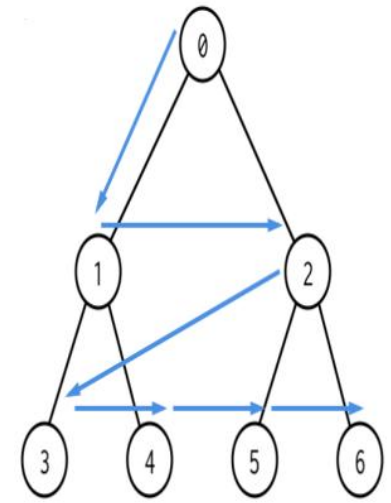

Gambar 5. Breadth Fisrt Search

3) Teknik Best First Search

Teknik penelusuran jenis ini dikenal juga sebagai penelusuran heuristic. Keuntungan dari jenis pencarian seperti ini adalah mengurangi beban komputasi pada sistem karena hanya solusi yang memberikan harapan saja yang diuji dan akan berhenti apabila solusi mendekati yang terbaik. Ini merupakan model penelusuran yang menyerupai cara manusia dalam mengambil solusi yang dihasilkan.

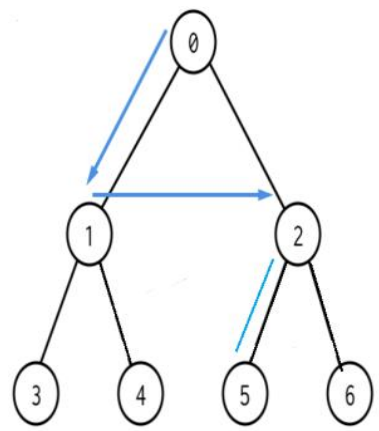

Gambar 6. Best First Search

\section{HASIL DAN PEMBAHASAN}

1. Struktur Basis Data

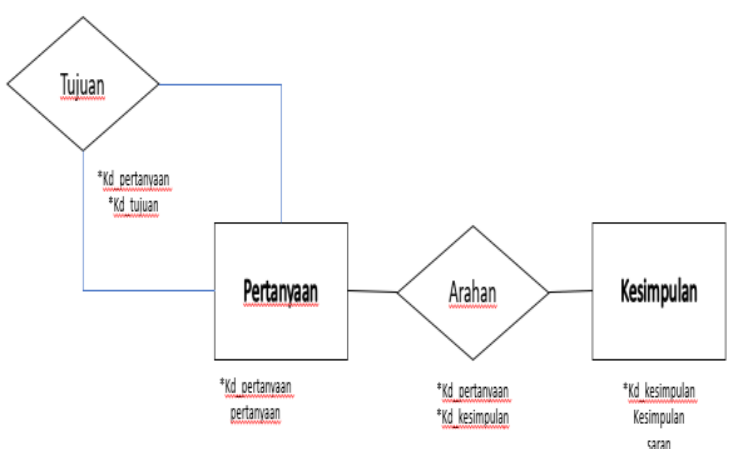

Gambar 7. ERD (Entity Relationship Diagram)

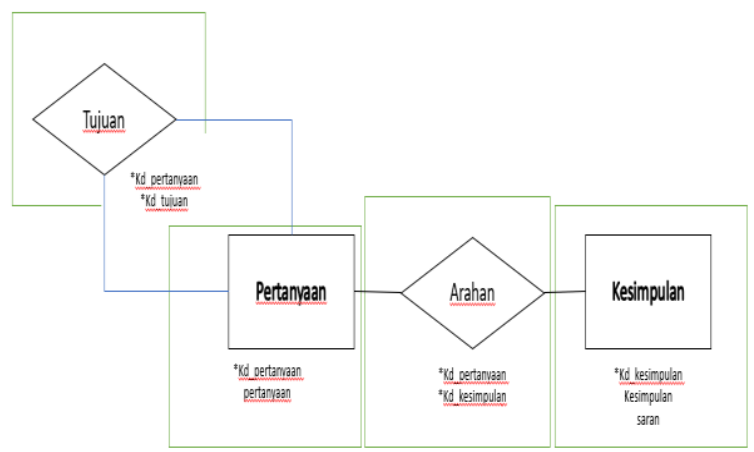

Gambar 8. Transformasi ERD ke LRS

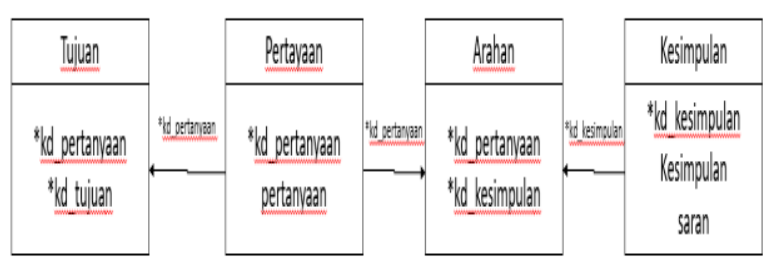

Gambar 9. LRS

Berikut ini adalah rancangan basis data hasil transformasi Logical Record Structure (LRS) ke Relasi (Tabel). Salah satu tabel pada aplikasi ini adalah tabel Pertanyaan yang berisi data pertanyaan berkaitan dengan gejala penyakit. 
Tabel 1. Tabel Pertanyaan

\begin{tabular}{cccc}
\hline Nama Field & $\begin{array}{c}\text { Tipe } \\
\text { Data }\end{array}$ & Panja ng & Keterangan \\
\hline Kd_pertanyaan & Char & 5 & $\begin{array}{c}\text { Kode } \\
\text { Pertanyaan } \\
\text { (PK) }\end{array}$ \\
pertanyaan & Char & 5 & \begin{tabular}{c} 
Pertanyaan \\
\hline
\end{tabular} \\
\hline
\end{tabular}

Tabel berikutnya yang digunakan pada aplikasi ini adalah tabel Simpulan yang berisi data mengenai simpulan dan saran.

Tabel 2. Tabel Simpulan

\begin{tabular}{cccc}
\hline Nama Field & Tipe Data & Panjang & Keterangan \\
\hline Kd_simpulan & Char & 5 & Kode \\
& & & $\begin{array}{c}\text { Simpulan } \\
\text { (PK) }\end{array}$ \\
& & & Simpulan \\
Simpulan & Varchar & 255 & Saran \\
saran & Varchar & 255 &
\end{tabular}

Tabel selanjutnya yang digunakan pada aplikasi ini adalah tabel Tujuan yang berisi data mengenai Tujuan.

Tabel 3. Tabel Tujuan

\begin{tabular}{cccc}
\hline Nama Field & $\begin{array}{c}\text { Tipe } \\
\text { Data }\end{array}$ & Panjang & Keterangan \\
\hline Kd_pertanyaan & Char & 5 & $\begin{array}{c}\text { Kode } \\
\text { Pertanyaan } \\
\text { (PK) }\end{array}$ \\
Kd_tujuan & Char & 5 & $\begin{array}{c}\text { Kode } \\
\text { Tujuan (PK) }\end{array}$ \\
\hline
\end{tabular}

Tabel selanjutnya yang digunakan pada aplikasi ini adalah tabel Arahan yang berisi data mengenai arahan.

Tabel 4. Tabel Arahan

\begin{tabular}{|c|c|c|c|}
\hline Nama Field & $\begin{array}{l}\text { Tipe } \\
\text { Data }\end{array}$ & Panjang & Keterangan \\
\hline Kd_pertanyaan & Char & 5 & $\begin{array}{c}\text { Kode } \\
\text { Pertanyaan } \\
\text { (PK) }\end{array}$ \\
\hline Kd_Simpulan & Char & 5 & $\begin{array}{l}\text { Kode } \\
\text { Simpulan } \\
\text { (PK) }\end{array}$ \\
\hline
\end{tabular}

Tabel berikut merupakan tabel Kamus yang berisi mengenai data kata dan keterangan dari istilah - istilah yang digunakan dalam diagnosa.

\section{Tabel 5. Tabel Kamus}

\begin{tabular}{cccc}
\hline Nama Field & $\begin{array}{c}\text { Tipe } \\
\text { Data }\end{array}$ & Panjang & Keterangan \\
\hline Kata & Char & 25 & Kata $($ PK) \\
Keterangan & Char & 255 & $\begin{array}{c}\text { Kode } \\
\text { Keterangan }\end{array}$ \\
\hline
\end{tabular}

Implementasi merupakan salah satu tahapan dalam pembuatan sistem. Sistem pakar ini dibuat dengan menggunakan bahasa pemrograman XML, Java, PHP dan database MySQL. Hasil implementasi dari bahasa pemrograman XML dan Java yaitu sebagai berikut:

\section{A. Tampilan Layar Splash Screen}

Pada gambar 10 berisikan tampilan layer splash screen yaitu tampilan saat membuka aplikasi.

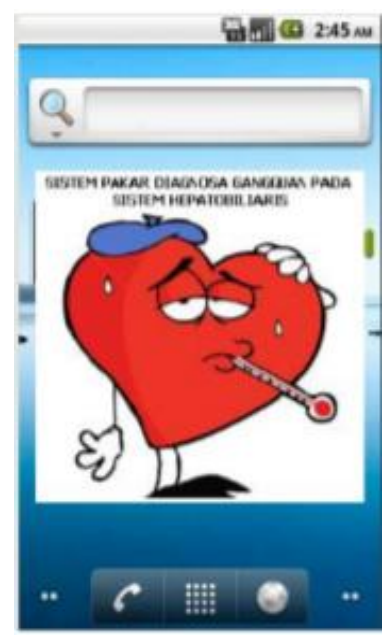

\section{Gambar 10. Tampilan Splash Screen}

\section{B. Tampilan Layar Menu Utama}

Pada gambar 10 berisi kegunaan sistem pakar dan terdapat 5 (lima) menu. Menu tersebut di antaranya: Diagnosa (menu ini digunakan untuk mendiagnosa gangguan pada sistem Hepatobiliaris), Panduan (digunakan sebagai petunjuk user dalam pemakaian aplikasi sistem pakar ini), Profil (digunakan untuk melihat profil dan informasi mengenai pembuat program), Admin (menu ini hanya dapat digunakan oleh admin), serta 
menu Keluar yang digunakan untuk keluar dari aplikasi ini.

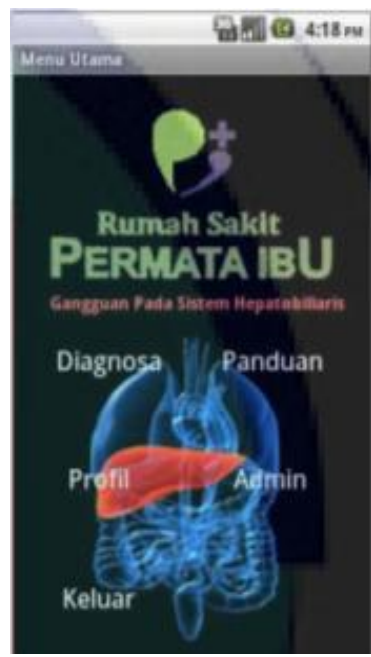

\section{Gambar 11. Tampilan Menu Utama}

C. Tampilan Layar Diagnosa

Pada gambar 12 berisi halaman untuk melakukan proses diagnosa Gangguan pada Sistem Hepatobiliaris (Hati, Empedu dan Pankreas). Setelah menu 'Diagnosa' dipilih, maka akan muncul pertanyaan pertama. Pada pertanyaan pertama, terdapat 2 (dua) pilihan: "Ya" dan "Tidak". Terdapat pula tombol "Sebelumnya" untuk kembali ke pertanyaan sebelumnya, tombol "Kamus" untuk ke halaman Kamus, serta tombol "Menu Utama" untuk kembali ke Menu Utama.

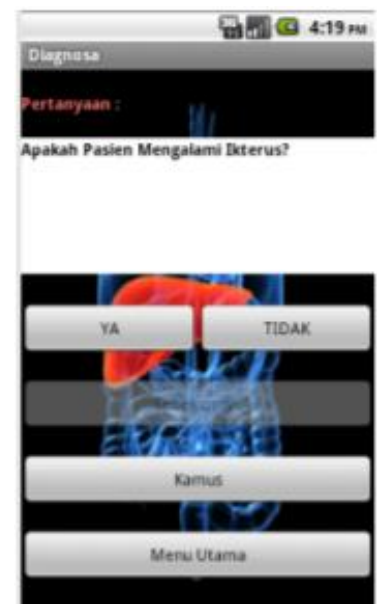

Gambar 12. Layar Diagnosa
D. Tampilan Layar Simpulan Pada gambar 13 terdapat simpulan nama penyakit dan saran.

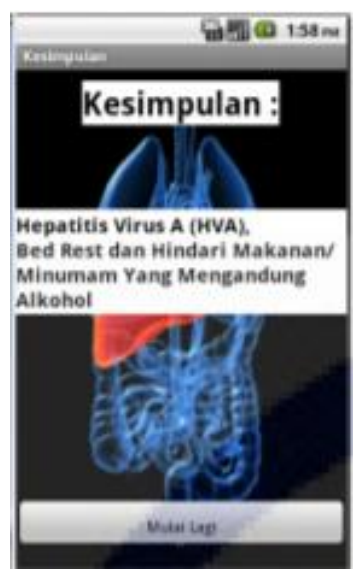

\section{Gambar 13. Layar Simpulan}

E. Uji Kasus

Pengujian program dilakukan untuk mengetahui apakah program sudah sesuai dengan tujuan pembuatan sistem pakar ini atau belum. Berikut ini adalah contoh pengoperasian program diagnosa gangguan pada sistem Hepatobiliaris untuk menuntun user dalam mengoperasikan program. Pada langkah pertama akan tampak layar halaman menu utama. Pada layar ini terdapat 5 (lima) menu, yaitu: "Diagnosa", "Panduan", "Profill", "Admin", dan "Keluar". Setelah itu pilih menu "Diagnosa", selanjutnya akan diarahkan ke halaman "Diagnosa". Pertanyaan pertama pada level pertama akan tampil pada halaman diagnosa, yaitu pertanyaan "Apakah Pasien Mengalami Ikterus?". Jika pada pertanyaan pertama dijawab "Tidak" maka akan tampil pertanyaan selanjutnya, yaitu "Apakah Pasien Tidak Mengalami Ikterus?”. Kedua pertanyaan ini berada dalam level pertama, jika user menjawab "Tidak" pada pertanyaan kedua, maka akan tampil layar tidak terdiagnosa yang menampilkan pesan "Tidak Dapat Didiagnosa". 

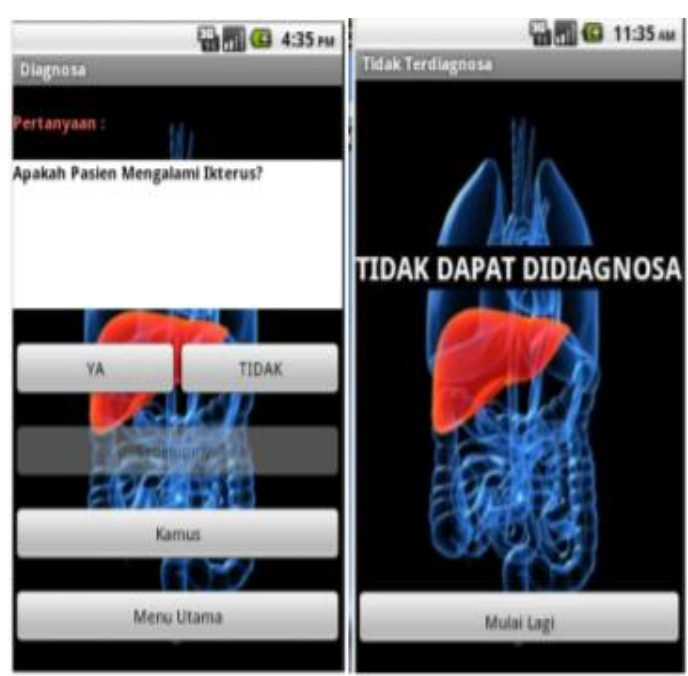

Gambar 14. Tampilan Layar Diagnosa Level Pertama

Langkah kedua adalah contoh pertanyaan pada level pertama. Apabila user menjawab "Ya" pada pertanyaan "Apakah pasien mengalami ikterus?", maka proses berlanjut ke pertanyaan selanjutnya di level kedua, yaitu "Apakah Pasien Mengalami Demam?". Jika sampai pada pertanyaan "Apakah Pasien Mengalami Pembengkakan Pada Perut?", dijawab “Tidak" semua, maka akan tampil halaman kemungkinan ada sembilan belas kemungkinan pada proses ini.

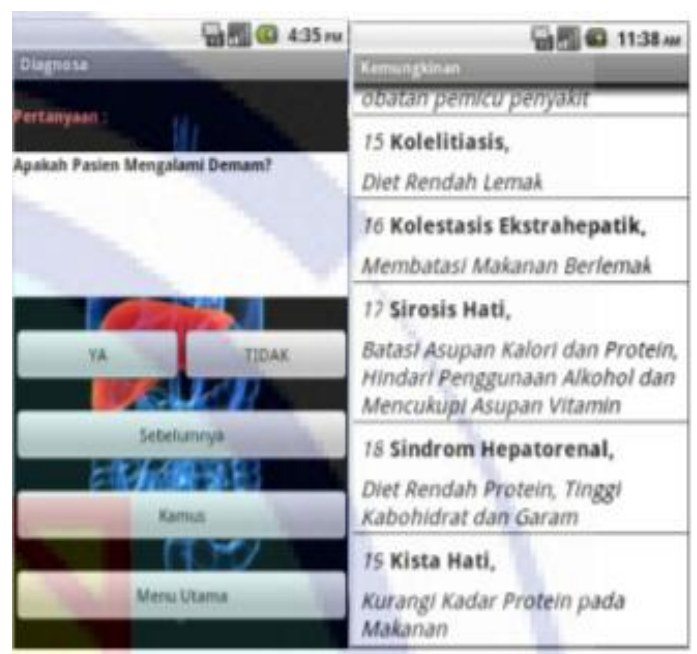

Gambar 15. Diagnosa Level kedua dan kemugkinan
Langkah ketiga adalah contoh pertanyaan pada level kedua. Apabila user menjawab "Ya" pada pertanyaan “Apakah Pasien Mengalami Demam?", maka proses berlanjut ke pertanyaan selanjutnya di level ketiga, yaitu “Apakah Pasien Mengalami Mual?". Jika sampai pada pertanyaan "Apakah Pasien Mengalami Rash?", dijawab "Tidak" semua, maka akan tampil halaman kemungkinan ada empat belas kemungkinan pada proses ini.

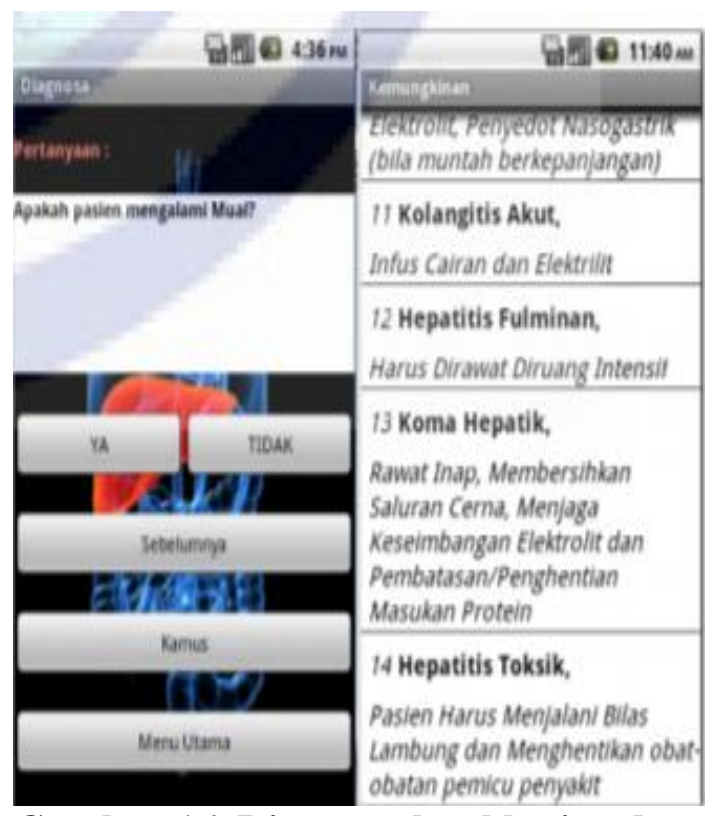

Gambar 16. Diagnosa level ketiga dan kemungkinan

Langkah keempat adalah contoh pertanyaan pada level ketiga. Apabila user menjawab "Ya" pada pertanyaan “Apakah Pasien Mengalami Mual?", maka proses berlanjut ke pertanyaan selanjutnya di level keempat, yaitu "Apakah Pasien Mengalami Hepatomegali?". Jika sampai pada pertanyaan "Apakah Pasien Merasakan Nyeri dan Menjalar Kebahu?" dijawab "Tidak" semua, maka akan tampil halaman kemungkinan ada sepuluh kemungkinan pada proses ini. 


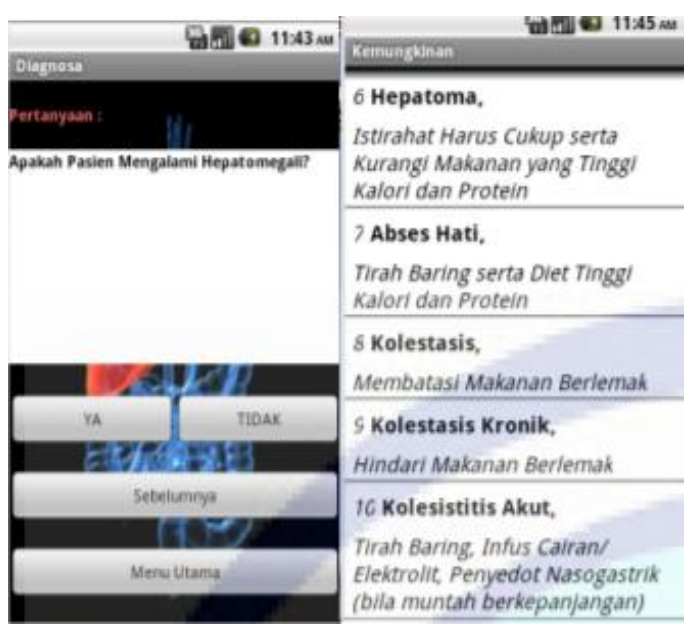

Gambar 17. Diagnosa ke empat dan kemungkinan.

Langkah kelima adalah contoh pertanyaan pada level keempat. Apabila user menjawab "Ya" pada pertanyaan "Apakah Pasien Mengalami Hepatomegali?", maka proses berlanjut ke pertanyaan selanjutnya di level kelima, yaitu "Apakah saat ikterus muncul, keluhan semakin berkurang?". Jika sampai pada pertanyaan "Apakah Pasien Mengalami Nyeri Pada Tulang?", dijawab "Tidak" semua, maka akan tampil sembilan kemungkinan.

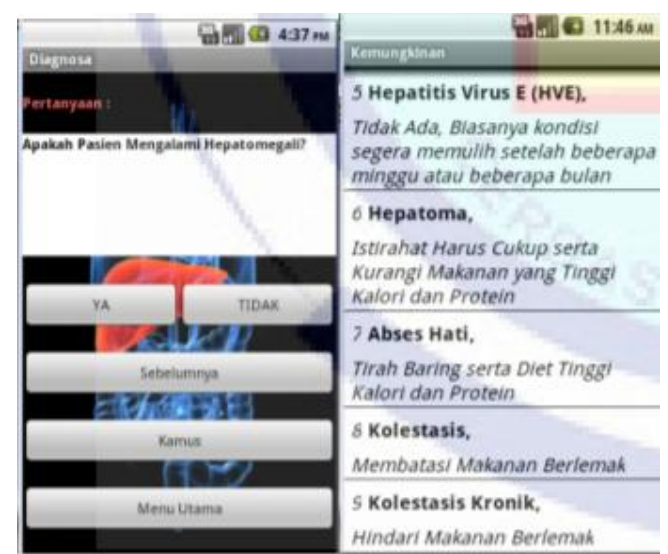

Gambar 18. Diagnosa level ke lima dan kemungkinan

Langkah keenam adalah contoh pertanyaan pada level kelima. Apabila user menjawab "Ya" pada pertanyaan "Apakah saat ikterus muncul keluhan semakin berkurang?", maka proses berlanjut ke simpulan, yaitu "Hepatitis Virus A (HVA), Bed Rest dan Hindari Makanan/Minuman Yang Mengandung Alkohol".

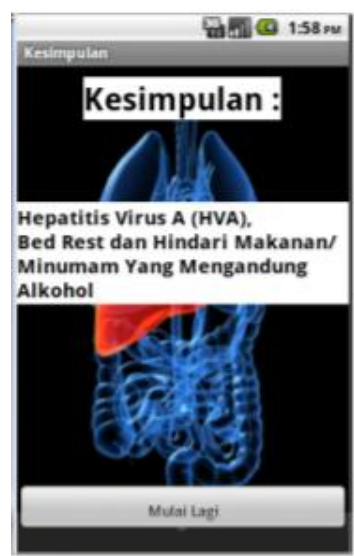

Gambar 19. Tampilan Simpulan

Pada tahap pengujian peneliti menggunakan metode pengujian blackbox.

\section{Tabel 6. Pengujian Blackbox}

\begin{tabular}{cccc}
\hline No & Fungsi & Berhasil & Tidak \\
\hline 1 & Splashscreen & $\sqrt{ }$ & \\
2 & Menu & $\sqrt{ }$ \\
& Utama & $\sqrt{ }$ \\
3 & Diagnosa & & \\
& Level 1 & $\sqrt{ }$ \\
4 & Diagnosa & \\
& Level 2 & $\sqrt{ }$ \\
5 & Diagnosa & \\
& Level 3 & $\sqrt{ }$ \\
6 & Diagnosa & $\sqrt{ }$ \\
7 & Level 4 & Diagnosa & $\sqrt{ }$ \\
8 & Level 5 & $\sqrt{ }$ \\
9 & Simpulan & Kamus & \\
\hline
\end{tabular}

\section{Simpulan}

\section{SIMPULAN}

Dari pembahasan mengenai sistem pakar untuk mendiagnosa gangguan pada sistem Hepatobiliaris, maka dapat dihasilkan beberapa simpulan sebagai berikut :

a. Diharapkan dengan adanya sistem pakar untuk mendiagnosa gangguan pada sistem Hepatobiliaris yang dibuat ini dapat membantu user dalam 
menemukan penyakit dan saran dengan waktu yang lebih singkat.

b. Sistem pakar ini berguna juga bagi para calon dokter terutama dokter muda yang belum berpengalaman untuk menyelesaikan masalah tanpa bantuan dokter yang lebih berpengalaman.

\section{Saran}

Beberapa saran yang kiranya dapat berguna berkaitan dengan pembuatan sistem pakar ini untuk menambah, memperbaiki serta meningkatkan kualitas dari sistem pakar ini adalah sebagai berikut:

a. Akan lebih baik lagi jika basis pengetahuan dalam program sistem pakar ini ditambah datanya dengan data yang baru karena dengan informasi yang terus berkembang maka data yang ada dalam sistem pakar ini selalu di-update secara berkala agar up to date.

b. Proses untuk mencari kemungkinan lebih disempurnakan lagi, karena membutuhkan waktu yang lama untuk mendapatkan kemungkinan.

c. Proses identifikasi akan lebih mudah bagi user jika dilengkapi fasilitas picture/video.

\section{DAFTAR PUSTAKA}

[1] Siswanto. Kecerdasan Tiruan. Yogyakarta: Graha Ilmu. 2010.

[2] RS, Pressman. Software Engineering : A Practitioner's Approach, $7^{\text {th }}$ ed. Mc Grow Hill. 2010.

[3] Mubin, A.Halim,Panduan Praktis Ilmu Penyakit Dalam : Diagnosis dan Terapi, Ed.2. Jakarta :EGC. 2006.

[4] W. Verina, "Penerapan Metode Forward Chaining untuk Mendeteksi Penyakit THT," JATISI, vol. 1, no. 2407-4322, p. 2, 2015. 